\title{
PENERAPAN METODE THINK PAIR SHARE DALAM MENINGKATKAN HASIL BELAJAR SISWA MATA PELAJARAN BAHASA INDONESIA KELAS VI SD NEGERI 168060 TEBING TINGGI
}

\author{
Nedi Kristina Simamora
}

Surel : nedikristina@gmail.com

\begin{abstract}
This aim of this research is to improve learning result on Indonesian langauge subject through think pair share method. This classroom action researchconducted by 2 cycles of the four phases: planning, implementation, observation, reflection. The subjects were students from class IV, SD N 168060 Tebing Tinggi which amounted to 35 students. This study used a qualitative descriptive analysis technique. The results showed that the use of the think pair share method of Indonesian language subjects can improve student learning result characterized by increased mastery learning students, namely pre-cycle (68,57\%), the first cycle $(77,14 \%)$, cycle II $(91,42$ $\%)$ and complete learn the clasical equal to $91,42 \%$.
\end{abstract}

Keywords : Think-Pair-Share, Indonesian Language, Learning Result

\begin{abstract}
ABSTRAK
Penelitian ini bertujuan untuk meningkatkan hasil belajar siswa mata pelajaran Bahasa Indonesia melalui metode think pair share. Penelitian tindakan kelas ini dilaksanakan sebanyak 2 siklus dengan empat tahapan yaitu : perencanaan, pelaksanaan, observasi, refleksi. Subjek penelitian ini adalah siswa Kelas VI SD N 168060 Tebing Tinggi sebanyak 35 siswa. Penelitian ini menggunakan teknik analisis dekriptif kualitatif. Hasil penelitian menunjukkan bahwa penggunaan metode think pair share mata pelajaran Bahasa Indonesia dapat meningkatkan hasil belajar siswa yang ditandai dengan peningkatan ketuntasan belajar siswa, yaitu pra siklus $(68,57$ $\%)$, siklus I $(77,14 \%)$, siklus II $(91,42 \%)$ dan dinyatakan berhasil ssecara klasikal 91,42\%.
\end{abstract}

Kata Kunci : Think-Pair-Share, Bahasa Indonesia, Hasil Belajar

\section{PENDAHULUAN}

Pembelajaran

bahasa

Indonesia saat ini telah mencakup seluruh aspek kebahasaan, maka siswa dituntut mampu berkomunikasi secara efektif, selalu menggunakan bahasa Indonesia sebagai alat komunikasi formal, memahami bahasa Indonesia dan menggunakannya dengan tepat, serta mampu membanggakan bahasa Indonesia sebagai budaya Indonesia.
Fungsi pembelajaran bahasa Indonesia adalah merupakan salah satu alat penting untuk mencapai tujuan Pendidikan Nasional, antara lain: (1) menanamkan, memupuk, dan mengembangkan perasaan satu nusa, satu bangsa, dan satu bahasa, (2) memupuk dan mengembangkan kecakapan berbahasa Indonesia lisan dan tulisan, (3) memupuk dan mengembangkan kecakapan berpikir dinamis, rasional, dan praktis, (4) 
memupuk dan mengembangkan ketrampilan untuk memahami, meng-ungkapkan dan menikmati keindahan bahasa Indonesia secara lisan maupun tulisan (Perwita, 2017).

Dengan bahasa, seseorang dapat mengekspresikan sikap dan perasaannya. Seseorang dapat menyampaikan segala hal yang berkecamuk dalam pikiran dan hatinya, tidak hanya dengan ekspresi dan gerak-gerik tubuh, tetapi juga dengan bahasa. Bahasa dapat pula dianggap sebagai alat komunikasi yang paling tepat. Dengan begitu guru harus bekerja keras untuk menampilkan sesuatu yang terbaik, sehingga siswa dapat merasa tertarik untuk mengikuti setiap materi yang akan diajarkan.

Pelajaran bahasa Indonesia mulai jenjang sekolah dasar (SD) sampai dengan sekolah menengah atas (SMA) berbasis teks. Dengan berbasis teks, siswa menggunakan bahasa tidak saja hanya dijadikan sebagai sarana komunikasi, tetapi sebagai sarana mengembangkan kemampuan berpikir. Oleh karena itu, pembelajaran berbasis teks ini perlu segera dipahami oleh pemerhati pengajaran bahasa Indonesia, guru bahasa Indonesia, mahasiswa, dan pihak-pihak yang terkait (Mahsun, 2017).

Tidak mudah bagi guru bahasa Indonesia untuk mengajarkan keterampilan berbahasa karena bahasa merupakan alat untuk berpikir dan belajar. Dengan adanya bahasa memungkinkan seseorang untuk berpikir secara abstrak.
Seseorang dapat memikirkan sesuatu meskipun objek yang dipikirkan itu tidak berada didekatnya. Model pembelajaran yang selama ini hanya menekankan pada pemikiran reproduktif, hafalan dan mencari satu jawaban yang benar terhadap soalsoal yang diberikan, sudah saatnya untuk ditinggalkan dan kini beralih ke proses berpikir kreatif dan inovatif, karena berpikir kreatif, inovatif dan produktif sangat dibutuhkan untuk menghadapi berbagai perubahan dan perkembangan ilmu pengetahuan dan teknologi.

Masalah yang diahadapi pada Kelas VI SD N 168060 adalah siswa menganggap sepele dengan pelajaran bahasa Indonesia karena bahasa Indonesia adalah bahasa sehari-hari dan menggap tidak perlu dipelajari. Selain itu rendahnya keterampilan siswa dalam berbicara dan menulis karena guru lebih menilai hasil belajar siswa secara tertulis melalui soal-soal tertuliskarena guru mengajar sesuai dengan target kurikulum yang ingin dicapai. Hal ini dapat dilihat dari nilai evaluasi ulangan harian pra siklus yang rendah yaitu dengan rata-rata nilai 68,7 dengan jumlah siswa yang lulus KKM 24 siswa $(68,57 \%)$.

Untuk dapat mengatasi masalah tersebut diatas, maka peneliti menerapkan metode think pair share pada pembelajaran bahasa Indonesia. Think pair share adalah suatu metode pembelajaran kooperatif yang memberi siswa untuk berpikir dan merespon serta 
saling bantu satu sama lain. Metode ini memperkenalkan ide "waktu berpikir atau waktu tunggu" yang menjadi faktor kuat dalam meningkatkan kemampuan siswa dalam merespon pertanyaan. Pembelajaran ini melatih siswa untuk berani berpendapat dan menghargai pendapat teman (Cholis : 2006: 12).

Metode Think-Pair-Share menekan-kan pada struktur khusus yang dirancang untuk mempengaruhi pola-pola interaksi siswa. Struktur ini menghendaki agar siswa kerja sama, saling melengkapi dan saling bergantung dalam kelompokkelompok kecil secara kooperatif. Metode Think-Pair-Sharemerupakan salah satu metode dengan memiliki struktur yang bertujuan untuk meningkatkan penguasaan akademik (Nurhadi, 2004: 119-120).

Metode Think-Pair-Share adalah salah satu tipe dalam pembalajaran kooperatif, yang dapat digunakansebagai alternatif bagi guru untuk mengajar. Metode pembelajaran Think-Pair- Share memiliki keistimewaan, yaitu siswa selain dapat mengembangkan kemampuan individunya sendiri, juga bisa mengembangkan kemampuan kelompoknya, sehingga dapat meningkatnya hasil belajar siswa dalam memecahkan masalh (Sutrisno, 2007:42).

Teknik think-pairs-Share (TPS) ini memberi kesempatan sedikitnya delapan kali lebih banyak kepada setiap siswa untuk dikenali dan menunjukan partisipasi mereka kepada orang lain. Teknik ini bisa digunakan dalam semua mata pelajaran dan untuk semua tingkatan usia anak didik. Langkah-langkah pembelajarannya adalah guru membagi siswa dalam kelompok berempat dan memberikan tugas kepada semua kelompok, setiap siswa memikirkan dan mengerjakan tugas tersebut sendiri, siswa berpasangan dengan salah satu rekan dalam kelompok dan berdiskusi dengan pasangannya; kedua pasangan bertemu kembali dalam kelompok berempat. Siswa mempunyai kesempatan untuk membagikan hasil kerjanya kepada kelompok berempat (Lie, 2007).

Berdasarkan permasalahan tersebut maka alternatif pendekatan pembelajaran yang tepat pada mata pelajaran bahasa Indonesia yaitu dengan metode think-pairs-share (TPS). Metode ini mengajarkan siswa untuk lebih mandiri dalam mengerjakansoal-soal yang diberikan sehingga dapat membangkitkan rasa percaya diri siswa,dimana siswa dapat bekerja sama orang lain dalam kelompok kecil yangheterogen khususnya pada mata pelajaran bahasa Indonesia.

Tujuan dari penelitian ini adalah untuk meningkatkan hasil belajar Bahasa Indonesia siswa Kelas VI SD Negeri 168060 Tebing Tinggi tahun pembelajaran 2017/2018 melalui metode think pair share.

\section{METODE PENELITIAN}

Peneliti mengambil lokasi penelitian tindakan kelas VI SD Negeri 168060 Tebing Tinggi. 
Penelitian ini mengenai kooperatif tipe Think Pair Share untuk meningkatkan hasil belajar siswa Kelas VI SDN 168060.

Subyek penelitian adalah siswa Kelas VI SD Negeri168060 Tebing Tinggi dengan jumlah siswa sebanyak 35 orang dengan 19 orang laki-laki dan 16orang perempuan. Sumber data yang digunakan adalah siswa dan teman sejawat. Pada Penelitian tindakan kelas data yang dikumpulkan dapat berbentuk kuantitatif maupun kualitatif.Data kuantitatif yang berupa nilai dianalisis dengan menggunakan analisis deskriptif komparatif yaiu membandingkan nilai tes kondisi awal, nilai tes setelah siklus I dan II yaitu nilai dari hasil ulangan harian siswa Kelas VI SD Negeri 168060Tebing Tinggi pada siklus I dan II.

Metode penelitian yang digunakan dalam penelitian ini adalah Classroom Action Research atau penelitian tindakan kelas. Model penelitian tindakan kelas yang digunakan peneliti adalah system spiral refleksi diri yang dikembangkan oleh Kemmis dan Taggart yang dimulai dengan perencanaan, tindakan, pengamatan, dan refleksi. Masing-masing siklus terdiri dari dua kali pertemuan yaitu sebagai berikut:

Pada tahapan ini dilakukan berbagai persiapan dan perencanaan tindakan yang meliputi: menyusun scenario pembelajaran berupa Rencana Pelaksaan Pembelajaran, mempersiapkan media pembelajaran dan alat observasi, dan membuat instrumen untuk evaluasi yang berupa soal tes tertulis. Selain mempersiapkan hal-hal tersebut, untuk dapat melaksanakan penelitian ini dengan tujuan yang jelas peneliti juga perlu menetapkan indikator ketercapaian dalam penerapan metode Think-Pairs-Share (TPS).

\section{Siklus I}

Guru melakukan pembelajaran di dalam kelas dengan menggunakan panduan perencanaan yang telah dibuat. Siklus I dilakukan pada tanggal 13November 2017. Penerapan metode think pairs sharedilakukan dengan siswa diminta untuk berfikir (think) tentang permasalahan yang disampaikan guru, Siswa diminta berpasangan (pairs) dengan teman sebangkunya (kelompok 2 orang) dan menggabungkan hasil pemikiran masing-masing, serta Guru memimpin pleno diskusi kecil, kelompok diminta mengemukakan hasil diskusinya (share). Materi yang dibahas pada siklus ini adalah mendeskripsikan secara lisan dan tulisan petunjuk penggunaan suatu alat.Pada saat kegiatan pembelajaran berlangsung guru sebagai peneliti dibantu oleh para observer lainnya untuk melakukan pengamatan, mendokumentasi kegiatan, selain itu peneliti bertindak sebagai fasilitator, motivator dan sekaligus sebagai pengamat. 


\section{Siklus II}

Guru melakukan pembelajaran di dalam kelas dengan menggunakan panduan perencanaan yang telah dibuat. Siklus II dilakukan pada tanggal 27 November 2017. Penerapan metode think pairs share dilakukan dengan siswa diminta untuk berfikir (think) tentang permasalahan yang disampaikan guru, Siswa diminta berpasangan (pairs) dengan teman sebangkunya (kelompok 2 orang) dan menggabungkan hasil pemikiran masing-masing, serta Guru memimpin pleno diskusi kecil, kelompok diminta mengemukakan hasil diskusinya (share). Materi yang dibahas pada siklus ini adalah memahami teks agak panjang (150200 kata), petunjuk pemakaian, makna kata dalam kamus/ensiklopedi. Pada saat kegiatan pembelajaran berlangsung guru sebagai peneliti dibantu oleh para observer lainnya untuk melakukan pengamatan, mendokumentasi kegiatan, selain itu peneliti bertindak sebagai fasilitator, motivator dan sekaligus sebagai pengamat. Pada Siklus kedua ini juga, suasana pembelajaran masingmasing kelompok di lingkungan sekolah dikondisikan agar tidak terlalu formal, maksudnya siswa bebas mengemukakan pendapatnya tentang materi ajar sesuai dengan kompetensi dasar yang ingin dicapai.

\section{Observasi/Pengamatan}

Observasi digunakan untuk pengumpulan data aktivitas belajar bahasa Indonesia siswa dalam pembelajaran. Pengumpulan data melalui observasi dilakukan secara partisipatif, yang berarti pengamat ikut serta dalam kegiatan belajar mengajar yang dilakukan oleh subjek yang diamati (Sanjaya, 2010: 92). Pengamatan dilakukan peneliti sendiri dan dibantu oleh pengamat dan mencatat proses penerapan teknik pengajaran kolaborasi.

\section{Refleksi}

Peneliti mengkaji, melihat dan mempertimbangkan hasil atau dampak dari tindakan yang dilakukan berdasarkan lembar pengamatan yang diisi oleh pengamat. Kegiatan pada tahap refleksi meliputi kegiatan menganalisis, memahami dan membuat kesimpulan berdasarkan hasil observasi setiap siklus. menemukan kelebihan dan kelemahan tindakan perbaikan pembelajaran. Hasil analisis data yang dilaksanakan pada tahap ini akan dipergunakan untuk menemukan kelebihan dan kelemahan diri dalam merancang dan melakukan tindakan sebagai acuan. Metode pengumpulan data penelitian ini adalah tertulis dan observasi. Penelitian ini dikatakan berhasil apabila siswa telah memperoleh nilai ketuntasan secara klasikal minimal $85 \%$ dari jumlah siswa dengan rumus sebagai berikut :

\footnotetext{
Persentase Ketuntasan klasikal $=$ Jumlah siswa yang tuntas $\times 100 \%$ Jumlah siswa yang mengikuti tes
} 


\section{HASIL PENELITIAN DAN PEMBAHASAN}

Kondisi awal siswa diketahui dengan memberikan tes kemampuan awal yang bertujuan untuk mengukur seberapa besar kemampuan yang dimiliki siswa dalam memahami materi yang akan disampaikan guru. Kemampuan siswa pada pra siklus dalam memahami materi pelajaran agak sulit. Sebelum dilakukan metode think-pair-share pada saat pembelajaran, siswa yang aktif cenderung sedikit sedangkan lebih banyak didominasi oleh siswa yang kurang aktif, sehingga dari sana akan mempengaruhi aktivitas belajar siswa. Adapun ciri-ciri yang menyebabkan aktivitas belajar siswa rendah yaitu dapat dilihat dari kurangnya minat siswa untuk mengancungkan tangan dalam menanggapi pertanyaan yang diberikan oleh guru, selain itu siswa kurang aktif untuk bertanya dalam proses pembelajaran, sehingga dari hal tersebut akan berpengaruh terhadap rendahnya hasil belajar siswa khususnya pada pelajaran bahasa Indonesia

Hasil penelitian tindakan kelas menunjukkan bahwa pengamatan yang dilakukan oleh mitra kolaborasi dan peneliti pada aktivitas guru dan siswa melalui penerapan metode think-pairs-share pada mata pelajaran Bahasa Indonesia Kelas VI SD Negeri 168060 Tebing Tinggi.

Berdasarkan pengamatan peneliti dari tindakan pra siklus, siklus I dan II terjadi peningkatan hasil belajar pada jumlah siswa dan persen ketuntasan belajar secara klasikal. Persentase ketuntasan belajar dapat ditingkatkan setelah diberikan tindakan pada siklus I, yaitu meningkat menjadi $77,14 \%$ dari $68,57 \%$ sebelum dilakukannya siklus I. Berarti terjadi peningkatan sebesar 8,57\%, dimana data pengamatan dilakukan dengan mencermati aktivitas siswa selama pelajaran berlangsung. Karena peneliti bertindak sebagai guru maka pengamatan dilakukan dengan lembar observasi khusus yang memudahkan dalam pencatatan data.

Pada siklus I muncul kekurangan, yaitu jumlahkelompok siswa yang dapat menunjukkan pekerjaannya di depan kelas masihterbatas. Hal ini dikarenakan terbatasnya soal yang diberikan pada siswa. Sehingga hanya dibutuhkan beberapa kelompok saja yang presentasi. Untuk selanjutnya soal latihan bisa dikembangkan dan akan lebih banyak siswa yang dapat menunjukkan eksistensinya dalam presentasi. Hasil ulangan siswa pada pelajaran bahasa Indonesia di Kelas VImasih tergolong kurang, yaitu memperoleh rata-rata 68,7, sedangkan Kriteria Kelulusan Minimal (KKM) yang harus dicapai siswa adalah 70. Dari 35 orang siswa yang mengikuti ujian pada pelajaran bahasa Indonesia hanya27 orang siswa atau $77,14 \%$ yang berhasil mendapatkan nilai di atas nilai 70 , sedangkan 8 siswa atau $22,85 \%$ mendapat nilai di bawah nilai 70.Hasil tersebut menunjukkan 
bahwa pada siklus pertama secara klasikal siswa belum tuntas belajar, karena siswa yang memperoleh nilai $\geq 70$ hanya sebesar $77,14 \%$ lebih kecil dari persentase ketuntasan yang dikehendaki yaitu sebesar $85 \%$.

Meskipun demikian, terjadi peingkatan hasil belajar siswa dari pra siklus ke siklus I walaupun hasilnya belum sesuai dengan indikator keberhasilan. Hal ini membuktikan bahwa dengan penerapan metode think-pairssharedapat meningkatkan hasil belajar siswa Kelas VI SD 168060. Nilai yang masih rendah disebabkan karena siswa belum terbiasa dengan metode Think-Pair-Share dan siswa perlu beradaptasi dengan metode tersebut. Hasil tersebut menggambarkan perlu adanyasuatu tahapan selanjutnya untuk memperbaiki hasil belajar agar target yang diharapkan dapat tercapai.

Pada dasarnya hambatan pada siklus I telah dapat diatasi dengan cukup baik. Hal ini terlihat dengan adanya peningkatan pada setiap indikator pencapaian yang telah ditetapkan. Persentase rata-rata aktivitas siswa telah dapat ditingkatkan dan penguasaan materi juga telah dapat memenuhi target pencapaian yang telah ditentukan sebelumnya. Selain itu dalam hal pengerjaan tugas dengan pasangan, hasilnya sudah baik. Peningkatan yang baik terlihat dari scor yang diperoleh siswa dari peran mereka dalam tugas kelompok.

Metode Think Pair Share dapat meningkatkan kemampuan siswa dalam mengingat suatu informasi dan seorang siswa juga dapat belajar dari siswa lain serta saling menyampaikan idenya untuk didiskusikan sebelum disampaikan di depan kelas. Think Pair Share menggunakan metode diskusi berpasangan yang dilanjutkan dengan diskusi pleno. Hal ini sejalan dengan pendapat Sutrisno (2007:42) yang menyebutkan bahwametode pembelajaran Think-Pair- Share memiliki keistimewaan, yaitu siswa selain dapat mengembangkan kemampuan individunya sendiri, juga bisa mengembangkan kemampuan kelompoknya, sehingga dapat meningkatnya hasil belajar siswa dalam memecahkan masalah.

$$
\text { Pada Tabel 1, metode }
$$
pembelajaran think-pairs-share pada siklus II diperolehnilai rata-rata ulangan harian siswa adalah 74,52 dan ketuntasan belajar mencapai $91,42 \%$ atau ada 32 siswa dari 35 siswa sudah tuntas belajar. Hasil tersebut menunjukkan bahwa pada siklus kedua secara klasikal sudah tuntas belajar, karena siswa yang memperoleh nilai $\geq 70$ sebesar 90,90 $\%$ sudah memenuhi kriteria dari persentase ketuntasan yang dikehendaki yaitu sebesar $85 \%$. Oleh karena itu dilanjutkan penelitian siklus kedua untuk meningkatkan hasil belajar siswa.

Pada siklus II, siswa sudah dapat bekerja sama dengan teman pasangannya. Pembelajaran yang dilaksanakan telah mampu meningkatkan hasil belajar siswa dan telah mencapai kriteria ketuntasan 
belajar yang diharapkan. Dengan penerapan metode think pairs share (TPS) dapat meningkatkan penguasaan materi siswa untuk mata pelajaran. Hal ini terlihat dari perbandingan hasil belajar siswa sebelumpemberian tindakan dengan setelah pemberian tindakan pada siklus I dan siklus II. Peningkatan yang baik dicapai setelah diberikannya tindakan dengan penerapanpembelajaran kooperatif model Think-Pairs-Share (TPS) dari siklus I ke siklus II sebesar 14,28\%. Dimana dari hasil tesyang diberikan persentase ketuntasan siswa mencapai $91,42 \%$ dengan rataratanilai 74,56 . Secara klasikal siklus II dinyatakan telah memenuhi kriteria penilaian.

Siswa dapat memahami konsep-konsep materi pembelajaran dengan baik karena siswa terlibat aktif pada saat proses kegiatan belajar. Siswa mencari tahu hal-hal penting mengenai materi melalui berpikir, bertukar pikiran dengan teman pasangannya serta mempresentasikan hasil diskusinya. Hasil belajar siswa ini digunakan untuk mengetahui sejauh mana pemahaman siswa terhadap materi pembelajaran yang telah disampaikan. Penerapan pembelajaran kooperatif model Think-Pairs-Share (TPS) dapat memberikan manfaat yang positif kepada siswa dan juga guru. Peningkatan mutu pembelajaran yang tercermin dari hasil belajar siswa dapat dicapai dengan penerapan model pembelajaran ini.
Karena model pembelajaran ThinkPairs-Share (TPS) ternyatatidak hanya menggunakan satu kemampuan, tetapi mengaitkan empat kemampuan, yaitu mendengarkan, membaca, menulis, dan berbicara. Selain itu dengan menggunakan pasangan-pasangan kelompok belajar dapat mengajarkan kepada siswa untuk saling berbagi pandangan atau pendapat dan menerima perbedaan.

Hasil penelitian yang telah dilakukan sejalan dengan pendapat Nurhadi (2004: 119-120) yang menyatakan bahwa metode ThinkPair-Share menekan-kan pada struktur khusus yang dirancang untuk mempengaruhi pola-pola interaksi siswa. Struktur ini menghendaki agar siswa kerja sama, saling melengkapi dan saling bergantung dalam kelompokkelompok kecil secara kooperatif. Metode Think-Pair-Share merupakan salah satu metode dengan memiliki struktur yang bertujuan untuk meningkatkan penguasaan akademik.

Selain itu peran guru juga mempengaruhi hasil belajar siswa. Guru harus mampu menciptakan suatu lingkungan belajar yang kondusif dan memahami kesulitan yang dihadapi siswa ketika pembelajaran berlangsung. Guru harus menghindari penyajian informasi dalam bentuk ceramah karena hal ini akan mengakibatkan kurangnya partisipasi siswa dalam kegiatan pembelajaran untuk memenuhi salah satu karakteristik 
model yang diharapkan siswa menjadi aktif dalam mencari dan mengolah sendiri informasi.

Guru berperan untuk menciptakan kondisi yang kondusif dan mendukungbagi terciptanya pembelajaran yang bermakna. Siswa (peserta didik) harus mengalami dan berinteraksi langsung dengan obyek yang nyata. Jadi belajar harus dialihkan yang semula berpusat pada guru menjadi pembelajaran yang berpusat pada siswa. Sekolah merupakan sebuah miniature dari masyarakat dalam proses pembelajaran harus terjadi saling kerja sama dan interaksi antar komponen. Pendidikan modern lebih menitik beratkan pada aktifitas yang sejati, di mana siswa belajar dengan mengalaminya sendiri pengetahuan yang dia pelajari.

Dengan mengalami sendiri, siswa memperoleh pengetahuan, pemahaman danketerampilan serta perilaku lainnya termasuk sikap dan nilai. saat ini pembelajaran diharapkan ada interaksi siswa pada saat pembelajaran. Hal ini agar siswa menjadi lebih aktif dan kreatif dalam belajar. guru berperan sebagai pembimbing danfasilitator. Dari hasil tes ini dapat dilihat bahwa hasil belajar dengan menggunakan metode pembelajaran think-pairs-share telah mampu meningkatkan hasil belajar siswa mengenai materi pelajaran bahasa Indonesia sesuai dengan indikator yang telah ditentukan sehingga tidak perlu lagi dilanjutkan pada siklus berikutnya dan dikatakan berhasil.

\section{Pembahasan}

Berdasarkan hasil yang didapat dari setiap siklus proses pembelajaran yang optimal, hal ini ditunjukkan dengan meningkatnya penguasaan materi dan hasil belajar siswa. Oleh karena itu dapat disimpulkan bahwa proses pembelajaran dengan penerapan inkuiris angat sesuai dengan mata pelajaran Bahasa Indonesia. maka Penelitian Tindakan Kelas (PTK) ini bisa dikatakan berhasil karena hasil peningkatan proses pembelajarannya optimal.

Gambaran peningkatan ketuntasan belajar yang diperoleh setelah melakukan penelitian dengan menggunakan metode think-pairsshareterlihat pada diagram berikut:

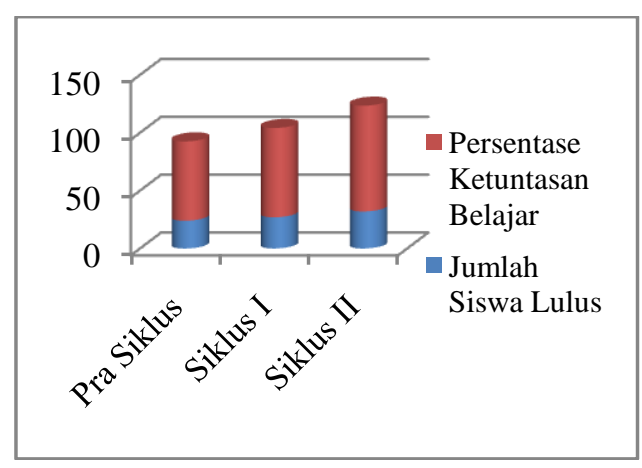

\section{Diagram 1. Peningkatan Ketuntasan Belajar}

\section{SIMPULAN}

Dari hasil temuan penelitian tentang hasil belajar siswa dengan metode kooperatif tipe group investigation di Kelas VI SD Negeri 168060 Tebing Tinggi berdampak positif dalam meningkatkan hasil belajar siswa. Hal tersebut dapat dilihat dari peningkatan persentase 
ketuntasan belajar siswa pada pra siklus $(68,57 \%)$, siklus I $(77,14 \%)$, siklus II $(91,42 \%)$.

\section{DAFTAR RUJUKAN}

Cholis, Sa'dijah. 2012. Penerapan Pembelajaran Kooperatif Think Pair Share TPS. Malang: Lembaga Penelitian UM.

Lie. A. 2007. Mempraktikan Kooperatif Learning di Ruang-ruang Kelas. Jakarta: Grasindo.

Nurhadi. 2004. Kurikulum 2004. Jakarta: Grasindo.

Perwita, S. A. 2017. Peningkatan Keterampilan Bercerita Pengalaman Dengan Menggunakan Metode Cooperative Script Mata Pelajaran Bahasa Indonesia Kelas $V$ Mi Tarbiyatut Tholabah Kranji-PaciranLamongan. Surabaya : Institut Agama Islam Negeri Sunan Ampel.

Sanjaya, Wina. 2010. Penelitian

Tindakan Kelas. Jakarta:

Kencana Prenada Media Group.

Sutrisno. 2007. Penerapan Pembelajaran kooperatif tipe Think-Pair-Share terhadap hasil belajar siswa. Widyatama, 4, 37-43. 